\title{
Antibacterial and cytotoxic activities of the Syzygium polyanthum leaf extract from Malaysia
}

\author{
Muhammad Luqman Nordin ${ }^{1}$, Abdul Aziz Othman ${ }^{2}$, Arifah Abdul Kadir ${ }^{2}$, Rumaizi Shaari ${ }^{1}$, Abdinasir Yusuf Osman ${ }^{1}$ and \\ Maizan Mohamed ${ }^{3}$ \\ 1. Department of Clinical, Faculty of Veterinary Medicine, Universiti Malaysia Kelantan, Pengkalan Chepa, 16100 Kota \\ Bharu, Kelantan, Malaysia; 2. Department of Veterinary Preclinical Sciences, Faculty of Veterinary Medicine, Universiti \\ Putra Malaysia, 43400 Serdang, Selangor, Malaysia; 3. Department of Veterinary Paraclinical Science, Faculty of \\ Veterinary Medicine, Universiti Malaysia Kelantan, Pengkalan Chepa, 16100 Kota Bharu, Kelantan, Malaysia. \\ Corresponding author: Muhammad Luqman Nordin, e-mail: luqman.n@umk.edu.my \\ Co-authors: AAO: azizothman.mppupm1314@gmail.com, AAK: arifah@upm.edu.my, RS: rumaizi@umk.edu.my, \\ AYO: abdinasir@umk.edu.my, MM: maizan.m@umk.edu.my \\ Received: 19-09-2018, Accepted: 21-12-2018, Published online: 12-02-2019
}

doi: 10.14202/vetworld.2019.236-242 How to cite this article: Nordin ML, Othman AA, Kadir AA, Shaari R, Osman AY, Mohamed M (2019) Antibacterial and cytotoxic activities of the Syzygium polyanthum leaf extract from Malaysia, Veterinary World, 12(2):236-242.

\begin{abstract}
Background and Aim: The increasing prevalence of drug resistance eventually leads scientist to discover new drugs that could solve the problem. Since ancient immemorial times, medicinal plants generally known as herbs were widely used in every culture throughout the world. In fact, currently up to 70,000 plant species have been screened for biological activities and about $70 \%$ ends up for commercialization. Therefore, this study was aimed to evaluate the potential cytotoxic and antibacterial effect of Syzygium polyanthum leaves which are local Malaysia plants, against 4T1 and MCF-7 mammary carcinoma cells, respectively, and also against bacteria causing mastitis in cows.
\end{abstract}

Materials and Methods: The cytotoxic effect of hydromethanolic extract of $S$. polyanthum against 4T1 and MCF-7 mammary carcinoma cells was evaluated using 3-(4, 5-dimethylthiazol-2-yl)-2,5-diphenyltetrazolium bromide) assay. The cells were treated with the concentration of extracts ranging from $15.63 \mu \mathrm{g} / \mathrm{mL}$ to $1000 \mu \mathrm{g} / \mathrm{ml}$ for $72 \mathrm{~h}$, and the percentage of cell survivability was determined based on minimum concentration that was able to allow at least $50 \%$ growth of cancer cells $\left(\mathrm{IC}_{50}\right)$ after $72 \mathrm{~h}$. The antibacterial activity was tested against common bacteria causing mastitis in cow. The bacteria were isolated from milk samples. The antibacterial activity of the extract was determined by disk diffusion method and susceptibility test based on minimum inhibitory concentration (MIC).

Results: Staphylococcus aureus, Staphylococcus hyicus, and Staphylococcus intermedius were isolated from the milk samples that positive for mastitis. The MIC values range from $7.12 \mathrm{~mm}$ to $13.5 \mathrm{~mm}$. The extract exhibits the widest zone of inhibition $(13.5 \pm 0.20 \mathrm{~mm})$ at $1000 \mathrm{mg} / \mathrm{ml}$ of concentrations. The extract relatively has low cytotoxicity effect against $4 \mathrm{~T} 1$ and MCF-7 cells with $\mathrm{IC}_{50}$ values ranging from $672.57 \pm 59.42$ and $126.05 \pm 50.89 \mu \mathrm{g} / \mathrm{ml}$, respectively.

Conclusion: $S$. polyanthum exerts weak antibacterial activity and cytotoxic effect to mammary carcinoma cells. The extract does not toxic to cells. However, further study is recommended, especially, this plant should be tested for in vivo.

Keywords: antibacterial, cytotoxic, mastitis, Syzygium polyanthum.

\section{Introduction}

Mastitis is defined as an inflammation of parenchyma of the mammary glands characterized by physical, chemical, and bacteriological changes in milk and pathological changes in glandular tissues that deteriorate the quality and quantity of milk [1]. Mastitis constantly becomes a serious infectious problem in dairy goats worldwide. The annual economic consequences are approximately $\$ 35$ billion worldwide which include losses in milk production, sales, and also a high cost for treatments. Staphylococcus spp. has been identified to be the main causative agent that

Copyright: Nordin, et al. Open Access. This article is distributed under the terms of the Creative Commons Attribution 4.0 International License (http://creativecommons.org/licenses/by/4.0/), which permits unrestricted use, distribution, and reproduction in any medium, provided you give appropriate credit to the original author(s) and the source, provide a link to the Creative Commons license, and indicate if changes were made. The Creative Commons Public Domain Dedication waiver (http://creativecommons.org/ publicdomain/zero/1.0/) applies to the data made available in this article, unless otherwise stated. contributes to goat's mastitis. Recently, the abundant uses of antibiotics without control resulting in antimicrobial resistance issue cause failure of mastitis treatment and increase in operation cost, especially, to the farmers due to the absence of effective antimicrobials medication.

Cancer is a non-infectious disease that is very complex and life-threatening to the well-being of the human population. Cancer that occurs in humans and other organisms arises from a single cell which has undergone genetic change due to interaction from external factors and genetic susceptibility of the host. The World Health Organization, 2016 (WHO, 2016), reported that septicemia due to bacterial infections and cancer diseases are the top three most common certified death among human population after cardiovascular disease.

Currently, many anticancer drugs develop drug resistance toward cancer [2,3]. Some of the cancers develop mutation and inherited genetic changes that 
can modify the drug's target site. It is also happening to antibiotics. Some of the bacteria develop enzymes that are capable of digesting and destroying antibiotics molecule. Moreover, it is expected to face more resistant bacteria in the near future [4]. Antibacterial resistance is a serious clinical challenge worldwide [5]. Therefore, natural antibacterial products are critical to achieve more diverse antibacterial combinations [5]. Therefore, the emerging of drugs resistance issue has drawn the scientist to find a potential source of treatment to encounter those problems.

A medicinal plant is generally known as a herb. The idea of using herbs as medicines to treat various human ailments including to treat wound, bacterial infections, and cancer diseases is not a new approach. They have been used since ancient civilizations [6]. There are lists of more than 3000 plant species that have reportedly exhibited anticancer properties, and approximately 100 plants with bioactive compounds are on pre-clinical development trials $[7,8]$. The WHO estimated that $80 \%$ of the population, especially, from developing countries rely on traditional medicines mostly plant origin for their health care. Several reports indicating that snake venom contains enzymes and toxins with antimicrobial and anticancer properties and can help to prevent the growth of bacteria have been reported $[9,10]$.

Syzygium polyanthum (Wight) Walp. var. Polyanthum (Figure-1) is wild evergreen shrub which belongs to the family of Myrtaceae. It is well distributed in Indonesia and also Malaysia. It is commonly known as "Daun Salam" or "Indonesian Bay Leaf." The leaves of "Daun Salam" are often used by Malays as a spice due to its flavor $[11,12]$.

S. polyanthum is known traditionally to treat diarrhea, rheumatism, and diabetes $[13,14]$. The leaves are freshly consumed as "ulam" by traditional Malay people for the treatment of hypertension and general body health maintenance [15]. In Indonesia, local people often add leaves in culinary preparation because they believe that the plant is beneficial in the management of diabetes mellitus, gout, arthritis, and hypertension [16].

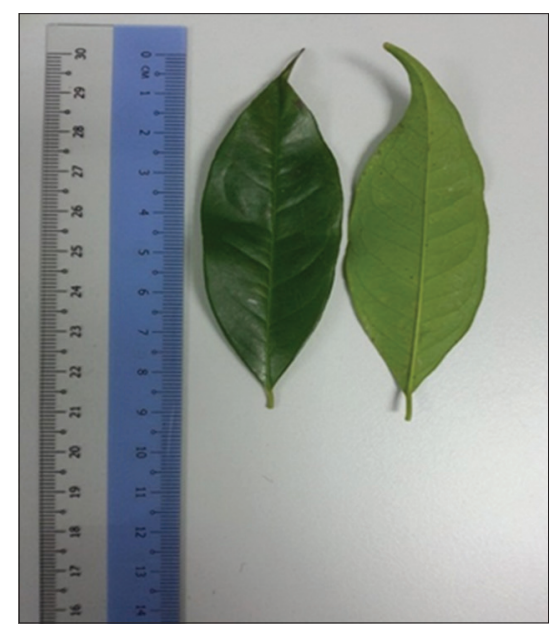

Figure-1: Syzygium polyanthum leaves.
This study was conducted with the intention to discover the true potential local herbs for mastitis in dairy cattle, which has antibacterial activity and, at the same time, does not toxic to cells. Perhaps, this study could be further evaluated by the other researchers to find the active compound from these plants. Furthermore, these herbs could be used synergistically with available commercial ones and subsequently improve the prognosis of the treatment and complementary methods such as using herbs or vitamins during treatment is not something new and in many things in help.

This study was performed to provide scientific validation regarding ethnopharmacological values that claim by the traditional practitioner. The findings pertaining to its cytotoxic and antibacterial properties of the $S$. polyanthum leaf extract could provide the true potential of the local herbs. It could be used as alternative medicine or perhaps synergistically used with available treatment to improve the prognosis of the disease.

\section{Materials and Methods}

\section{Ethical approval}

Not applicable in this study.

\section{Collection and identification}

S. polyanthum Lam. fresh leaves were collected from Biodiversity Unit, Universiti Putra Malaysia (UPM). The leaves were certified with a deposited voucher specimen (SK 2835/15) from the Herbarium of Natural Products, IBS, UPM. The collected leaves were rinsed with distilled water, cleaned, and then dried in oven for 7 days.

\section{Extraction of plant leaves}

The dried leaves of $S$. polyanthum were pulverized using a commercial blender. About $400 \mathrm{~g}$ of pulverized leaves were soaked in methanol:distilled water $(80: 20, \mathrm{v} / \mathrm{v})$ in a conical flask for $72 \mathrm{~h}$. The flask was continually shaking daily for 3 consecutive days. The solution was filtered using Whatman No. 42 filter paper to separate solvent-containing extract. The extract was evaporated using a vacuum rotary evaporator (Heidolph German) and controlled heating bath at $30^{\circ} \mathrm{C}$. The extract yield was stored in the refrigerator until used for the analysis.

\section{Bacterial strains}

The antibacterial potency of plant extract was evaluated using three bacterial strains causing mastitis in cow. The bacterial strains were isolated from milk samples from 10 dairy cows having mastitis. The mastitis cow was detected based on gross signs of udder infection during physical examination, appearance of abnormal milk production, and also California Mastitis Test (CMT). Milk samples were inoculated onto blood agar plates and MacConkey agar, respectively. Inoculated plates were then incubated aerobically at $37^{\circ} \mathrm{C}$ for $24-48 \mathrm{~h}$. Secondary culture was performed to obtain a pure culture. The purified bacterial 
strains were confirmed based on colony morphology, gram staining, and biochemical test.

\section{Antibacterial activity of extracts}

The antibacterial assay of hydromethanolic extract was performed according to the method described by Bauer et al. [17] with a slight modification. The Mueller-Hinton Agar media, along with the inoculum (106 CFU/ml), were poured into the Petri dishes. For the agar disk diffusion method, sterile filter paper disk was saturated with $125,250,500$, and $1000 \mathrm{mg} / \mathrm{ml}$ of the extract, allowed to dry, and then placed on the upper layer of the seeded agar plate. The plates were incubated overnight at $37^{\circ} \mathrm{C}$. Antibacterial activity was determined by measuring the diameter of the zone of inhibition ( $\mathrm{mm}$ ) surrounding bacterial growth strains. The bacterial strains were isolated from milk samples of mastitis dairy cattle.

\section{Minimal inhibitory concentration (MIC)}

S. polyanthum extract was tested for the MIC test using the broth dilution method according to Jorgensen and Turnidge [18]. A different concentration of the tested material was obtained by four rows in each containing $125,250,500$, and $1000 \mathrm{mg} / \mathrm{ml}$. Then, $0.5 \mathrm{ml}$ of bacterial suspension was filled to each tube to achieve a final concentration of $1-5 \times 10^{5} \mathrm{CFU} / \mathrm{ml}$. Two sets of controls were set for each tube which contained (a) positive control consisting of broth and bacterial suspension and (b) negative control only consisting of broth. Afterward, the tubes were incubated for $24 \mathrm{~h}$ incubation at $37^{\circ} \mathrm{C}$. The tubes were observed for visible bacterial growth as evidenced by turbidity. Color changes were observed, and the tubes with colorless appearance were taken as a positive. The lowest concentration of extracts which tubes with colorless indication was recorded as the MIC value. The average values were calculated for the MIC of the test material.

\section{Minimum bactericidal concentration (MBC)}

After identification of the MIC, inoculum from each tube was streaked into agar plate and incubated at $37^{\circ} \mathrm{C}$ for $24 \mathrm{~h}$. The streaks from each tube that exhibits prevention of bacterial growth was recorded as $\mathrm{MBC}$ values. Streaks were taken from the two lowest concentrations of the plant extract plates exhibiting invisible growth. One streak from each tube that exhibits prevention of bacterial growth was recorded as MBC values.

\section{Cytotoxicity activity}

Cytotoxic activity of $S$. polyanthum extract was conducted according to the method described by Baharum et al. [19] and Nordin et al. [20]. Cytotoxicity activity of $S$. polyanthum extract was prepared with concentrations ranging from $15.63 \mu \mathrm{g} / \mathrm{mL}$ to $1000 \mu \mathrm{g} / \mathrm{mL}$. The seeding cell density was $1 \times 10^{5}$ cells $/ \mathrm{mL}$ of mouse mammary carcinoma cell line (4T1). The cells were obtained from the American Type Culture Collection (ATCC, USA). The cancer cell was grown in RPMI 1640 medium supplemented with L-glutamine, 10\% fetal bovine serum, and $1 \%$ antibiotic as a complete growth medium. The experiment was repeated thrice, and the percentage of cell survivability versus concentration was calculated according to the following equation [19]:

$$
\text { Cell viability }(\%)=\frac{\text { Mean OD of treated cell- }}{\begin{array}{l}
\text { Mean OD of blank } \\
\text { Mean OD of blank }
\end{array}} \times 100 \%
$$

The cytotoxic effect of $S$. polyanthum extract against 4T1 was recorded as $\mathrm{IC}_{50}$ and compared with untreated cells according to the method described by Nordin et al. [20] and Ayob et al. [21].

\section{Statistical analysis}

All the percentages of the zone of inhibition values were expressed as mean $(n=3)$ per plate \pm standard deviation (SD) and were analyzed using oneway ANOVA. The test was considered statistically significant when $\mathrm{p}<0.05$ while all the percentages of cell survivability were expressed as mean $(n=3)$ per plate \pm SD for triplicate and analyzed using one-way ANOVA followed by Dunnett's multiple comparison test. $* \mathrm{p}<0.05, * * \mathrm{p}<0.01$, and $* * * \mathrm{p}<0.001$ denote significant difference as compared to untreated cell $(0 \mu \mathrm{g} / \mathrm{ml})$.

\section{Results}

\section{Bacterial culture}

Eighteen dairy cows with 68 milk samples were successfully examined, and had clinical mastitis. The diagnosis was further conducted using CMT to confirm the mastitis. The samples were scored as in Table-1. The prevalence of CMT positive was $42.64 \%$ and cultured on blood agar. Twenty of 29 samples cultured successfully grown.

\section{Bacterial identification}

On plate morphology, the results showed the presence of Staphylococcus aureus. S. aureus was in size about $2 \mathrm{~mm}$, having a circular shape with a flat surface and the color was whitish opaque gray with smooth edge and shiny appearance. Staphylococcus hyicus about having the same characteristic with

Table-1: Milk scores using CMT.

\begin{tabular}{lccccccc}
\hline Number of animals & Number of milk samples & \multicolumn{4}{c}{ CMT scores } & \multicolumn{2}{c}{ Positive samples (\%) } \\
\cline { 2 - 5 } & & $\mathbf{0}$ & $\mathbf{1}$ & $\mathbf{2}$ & $\mathbf{3}$ & \\
\hline 18 & 68 & 16 & 23 & 22 & 7 & 42.64 \\
\hline
\end{tabular}

CMT=California mastitis test 
Table-2: Biochemical characteristic of Staphylococcus aureus, Staphylococcus hyicus, and Staphylococcus intermedius.

\begin{tabular}{|c|c|c|c|c|c|c|c|}
\hline Cat & Coa & BB & VP & Mal & Man & ADH & Bacteria identification \\
\hline+ & & & & & & + & Staphylococcus hyicus \\
\hline+ & + & + & + & + & + & & Staphylococcus aureus \\
\hline+ & + & + & + & + & + & & Staphylococcus intermedius. \\
\hline
\end{tabular}

Cat $=$ Catalase, $\mathrm{Coa}=$ Coagulase, $\mathrm{BB}=\mathrm{Blood}$ broth, $\mathrm{VP}=$ Voges-Proskauer, $\mathrm{Mal}=$ maltose, $\mathrm{Man}=$ Mannitol, $\mathrm{ADH}=\mathrm{Arginine}$ Dihydrolase

Table-3: Frequency of bacteria strains isolated from grown CMT-positive milk.

\begin{tabular}{lc}
\hline Isolates & Number of isolates (\%) \\
\hline Staphylococcus aureus & $6(42.8)$ \\
Staphylococcus hyicus & $4(28.6)$ \\
Staphylococcus intermedius & $4(28.6)$ \\
Total & $14(100)$ \\
\hline
\end{tabular}

S. aureus without giving any hemolysis character on blood agar.

On the other hand, Staphylococcus intermedius also seems to be opaque white, low convex and have smooth edges. The colony size is about $2-4 \mathrm{~mm}$ in diameter and sometimes bigger than $S$. aureus. This was followed by gram staining which yielded $15 \mathrm{Gram}$ positive cocci bacteria with catalase positive, 2 Grampositive cocci with catalase negative, 1 Gram-negative bacteria with small rod, and 2 of them were Grampositive filamentous bacteria with slow catalase-positive reaction. Various biochemical tests were used to identify the isolates. It started from gram-staining where if the results were positive, then catalase will proceed, and if it positive too, the result of the coagulase test will determine the biochemical test used. Table- 2 shows the list of tests used for coagulase-positive bacterial strains.

From these various biochemical tests that have been used to identify the species isolates, it was found that the $S$. aureus, $S$. hyicus, and $S$. intermedius were identified as in Table-2. S. aureus was the most common bacteria isolated (6 of 14 isolates) followed by $S$. hyicus and S. intermedius, in which both of them were 4 isolates of 14 (Table-3).

\section{Minimum inhibitory concentration (MIC)}

Three most common bacteria isolates which were $S$. aureus, $S$. hyicus and $S$. intermedius were chosen to be tested with hydromethanolic extract of $S$. polyanthum (Table-3). Table-4 shows the mean diameter of the zone of inhibition produced by different concentrations of extract. The zone of inhibition was measured in millimeters (mm) (Figure-2).

The $S$. polyanthum extract shows the largest zone of inhibition at $1000 \mathrm{mg} / \mathrm{ml}$ concentration against $S$. aureus which was $13.5 \mathrm{~mm}$ in diameter. The sensitivity reduced as the concentration of plant extract decreased. The treatment effect was time-dependent manner. When compared to the positive control, $S$. hyicus was the most sensitive toward amoxicillin followed by $S$. aureus and S. intermedius. On the other hand, 3\% DMSO which was used as negative control also failed to inhibit any bacteria.

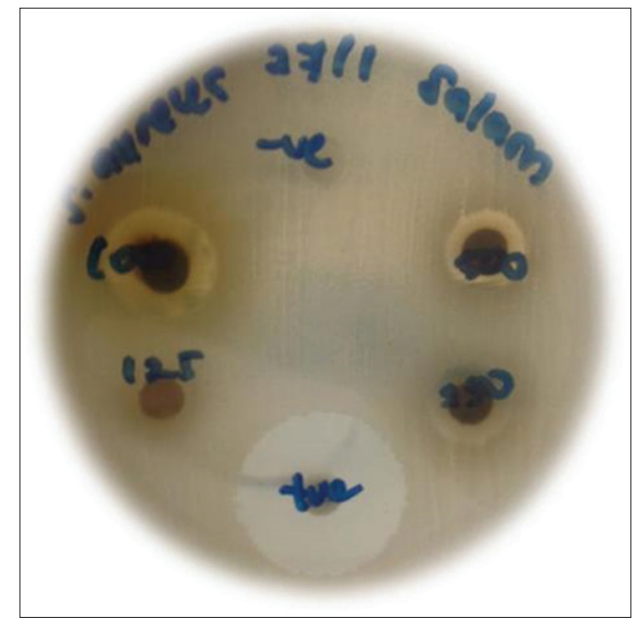

Figure-2: Growth zone of inhibition of some of the bacteria (Staphylococcus aureus) caused by Syzygium polyanthum extract.

MIC was determined on 96 plates by quantitative evaluation. Table-5 shows that MIC for $S$. polyanthum extract was at a concentration of $125 \mathrm{mg} / \mathrm{ml}$ against all bacteria tested. In meanwhile, the MBC was similar which is at $125 \mathrm{mg} / \mathrm{ml}$. The inhibitory concentration of $S$. polyanthum extract started at $125 \mathrm{mg} / \mathrm{ml}$ with the zone of inhibition of $8.00 \pm 0.61 \mathrm{~mm}$ for $S$. aureus, $7.62 \pm 0.12 \mathrm{~mm}$ for $S$. hyicus, and $7.12 \pm 0.29 \mathrm{~mm}$ for $S$. intermedius. The MBC of the plant extract was confirmed by the absence of bacterial growth of the isolated bacteria when streaked from inhibition zone corresponding to their lowest MIC values. The MBC of the S. polyanthum was also at $125 \mathrm{mg} / \mathrm{ml}$ suggested that the plant can be used to prevent and control mastitis in dairy cattle.

\section{Effect of crude hydromethanolic extract of S. polyanthum}

For the cytotoxic screening, S. polyanthum extract shows the cell survivability (\%) of 4T1 and MCF-7 with a dose-dependent manner (1000-15.63 $\mu \mathrm{g} / \mathrm{ml})$. Overall, the extract does not exhibit strong cytotoxic activities, showing that more than $50 \%$ cells were viable when treated with plant extracts at a concentration of $100 \mu \mathrm{g} / \mathrm{ml}$ and above. The $\mathrm{IC}_{50}$ values for the extract against both cancer cells were more than $100 \mu \mathrm{g} / \mathrm{ml}$ (Figures-3 and 4). Table-6 shows the $\mathrm{IC}_{50}$ values of $S$. polyanthum on 4T1 and MCF-7 mammary carcinoma cell lines. The inhibition of cell viability was more than $50 \%$ in $4 \mathrm{~T} 1$ and MCF-7 after treatment with $S$. polyanthum extract at the concentration $672.57 \pm 59.42$ $\mu \mathrm{g} / \mathrm{mL}$ and $126.05 \pm 50.89 \mu \mathrm{g} / \mathrm{mL}$, respectively. 
Table-4: Mean diameter zone of inhibition produced by hydromethanolic extract of Syzygium polyanthum against respective bacteria.

\begin{tabular}{|c|c|c|c|c|c|}
\hline \multirow[t]{2}{*}{ Plant extract } & \multicolumn{2}{|c|}{ Concentration } & \multicolumn{3}{|c|}{ Zone of inhibition ( $\mathrm{mm}$ ) } \\
\hline & $\%$ & $\mathbf{m g} / \mathbf{m l}$ & Staphylococcus aureus & Staphylococcus hyicus & Staphylococcus intermedius \\
\hline Syzygium & 100 & 1000 & $13.50 \pm 0.20^{\mathrm{a}}$ & $12.00 \pm 0.35^{\mathrm{a}}$ & $12.87 \pm 0.31^{\mathrm{a}}$ \\
\hline \multirow[t]{3}{*}{ polyanthum } & 50 & 500 & $11.62 \pm 0.23^{\mathrm{ab}}$ & $10.12 \pm 0.12^{a}$ & $10.00 \pm 0.40^{\mathrm{ab}}$ \\
\hline & 25 & 250 & $10.25 \pm 0.32^{b}$ & $8.25 \pm 0.25^{\mathrm{b}}$ & $8.87 \pm 0.23^{b}$ \\
\hline & 12.5 & 125 & $8.00 \pm 0.61^{c, d}$ & $7.62 \pm 0.12^{\mathrm{b}}$ & $7.12 \pm 0.29^{b}$ \\
\hline Amoxicillin & 100 & 10 & $21.81 \pm 0.35^{\mathrm{a}}$ & $33.87 \pm 0.39^{b}$ & $18.43 \pm 0.31^{c}$ \\
\hline
\end{tabular}

Value represent mean \pm SEM $(n=4)$. Means with different alphabets indicate significant differences among different concentrations

Table-5: MIC and MBC of plant extract against Staphylococcus aureus, Staphylococcus hyicus, and Staphylococcus intermedius.

\begin{tabular}{lcc}
\hline Plant extract & MIC (mg/ml) Syzygium polyanthum & MBC (mg/ml) Syzygium polyanthum \\
\hline Staphylococcus aureus & 125 & 125 \\
Staphylococcus hyicus & 125 & 125 \\
Staphylococcus intermedius & 125 & 125 \\
\hline
\end{tabular}

$\mathrm{MIC}=$ Minimum inhibitory concentration, $\mathrm{MBC}=$ Minimum bactericidal concentration

Table-6: $\mathrm{IC}_{50}$ values $(\mu \mathrm{g} / \mathrm{mL})$ of Syzygium polyanthum extract on 4T1 and MCF-7 mammary carcinoma cell lines.

\begin{tabular}{lc}
\hline Cancer cell lines & $\mathrm{IC}_{\mathbf{5 0}}$ values of extracts/drug $(\boldsymbol{\mu g} / \mathbf{m L})$ \\
\cline { 2 - 2 } & $\begin{array}{c}\text { Hydromethanolic extract of } \\
\text { Syzygium polyanthum }\end{array}$ \\
\hline $4 \mathrm{~T} 1$ & $672.57 \pm 59.42$ \\
MCF-7 & $126.05 \pm 50.89$ \\
\hline
\end{tabular}

All values are expressed as mean $(n=3) \pm S D$ of triplicate experiments

\section{Discussion}

Results obtained in the present study revealed that the hydromethanolic extract of $S$. polyanthum exhibits antibacterial activity against $S$. aureus, $S$. hyicus, and $S$. intermedius (Table-2). The plant extract was tested at a concentration of $125-1000 \mathrm{mg} / \mathrm{ml}$ to evaluate the inhibitory effects against bovine mastitis isolated pathogens. In this study, the MIC of $S$. polyanthum against mastitis bacteria in bovine was $125 \mathrm{mg} / \mathrm{ml}$. The antibacterial activity is considered weak (zone of inhibition between $<8 \mathrm{~mm}$ ) against $S$. aureus. This is in agreement with study by Mehta et al. [22] on Nelumbo nucifera flowers in which zone of inhibition between 10 and $16 \mathrm{~mm}$ is considered moderately potent. Another study conducted from Adina cordifolia, Asparagus racemosus, Aegle marmelos, Cassia tora, and Dillenia pentagyna extracts which were considered showed weak antibacterial activity in which zone of inhibition was between $5 \mathrm{~mm}$ and $8 \mathrm{~mm}$ [23]. This means that, in general, plant extract with zone of inhibition between 10 and $16 \mathrm{~mm}$ is considered moderately active while plant extract with zone of inhibition between $5 \mathrm{~mm}$ and $8 \mathrm{~mm}$ is considerate weakly active.

Ramli et al. [24] reported that the inhibition zone of $S$. polyanthum extract against $S$. aureus was $9.33 \pm 0.52 \mathrm{~mm}$. In this experiment, findings showed that the inhibition zone is proportional with concentration.

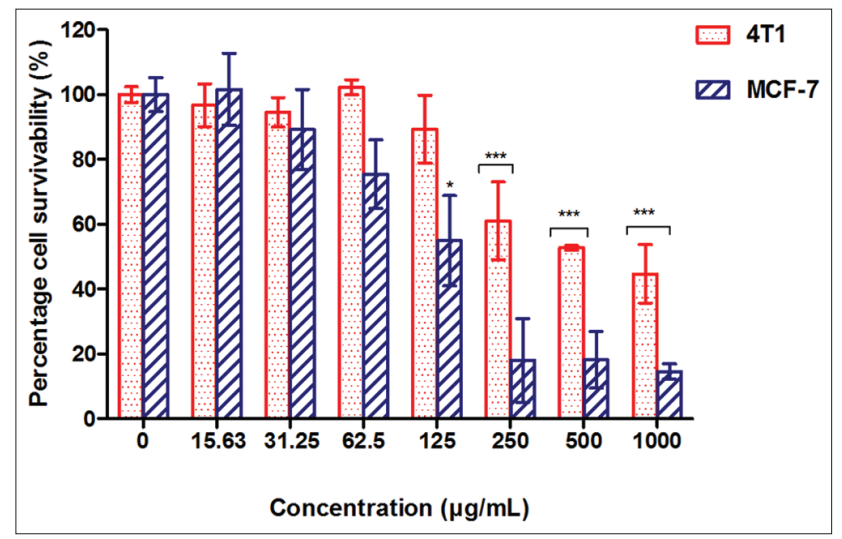

Figure-3: Cell survivability (\%) of 4T1 and MCF-7 cancer cells following treatment with Syzygium polyanthum extract for $72 \mathrm{~h}$.

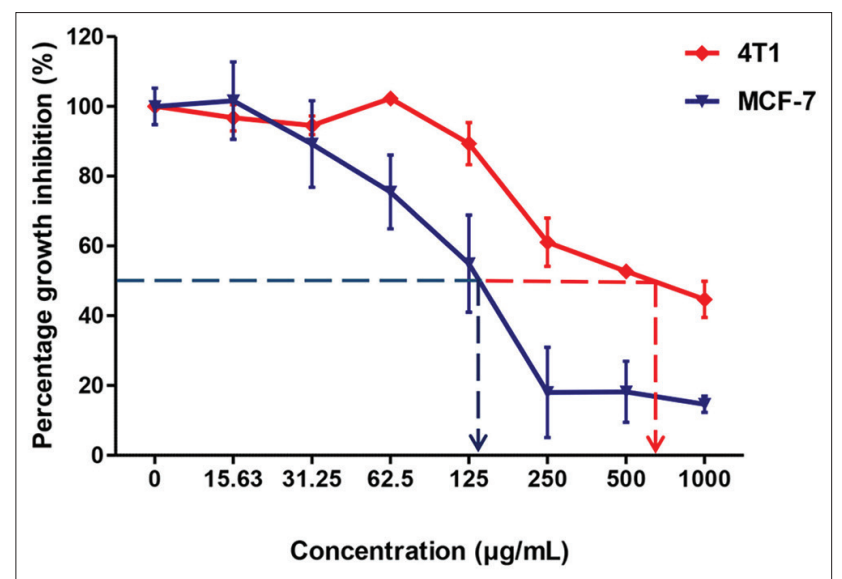

Figure-4: Minimum growth inhibitory concentration $\left(\mathrm{IC}_{50}\right.$ ) of Syzygium polyanthum extract on 4T1 and MCF-7 mammary carcinoma cell lines.

As the concentration of extract increases, the zone of inhibition is also wider. However, there is no difference in terms of pathogens susceptibility because the MIC and MBC values are the same which are at $125 \mathrm{mg} / \mathrm{ml}$. It means that these bacteria inhibited and 
killed at the same concentration of extract. This is in agreement with previous study using the same plant extract and Gram distinction between bacteria has an effect on susceptibility rate [24]. The similarity of MIC and MBC could be due to the pathogens tested in this experiment which were Gram-positive bacteria.

In general, $S$. polyanthum extract exhibits cytotoxic activity (when $\mathrm{IC}_{50}<1000 \mu \mathrm{g} / \mathrm{ml}$ ), but according to the United States National Cancer Institute plant screening program and report [25], the S. polyanthum extract was in category of weakly active against cancer cells $\left(\mathrm{IC}_{50}>100-1000 \mu \mathrm{g} / \mathrm{ml}\right)$. In this study, the minimum concentration of $S$. polyanthum extract that gives at least $50 \%$ of cell inhibition of $4 \mathrm{~T} 1$ and MCF-7 cells was $672.57 \pm 59.42$ and $126.05 \pm 50.89 \mu \mathrm{g} / \mathrm{ml}$, respectively. 3-(4,5-dimethylthiazol-2-yl)-2,5-diphenyltetrazolium bromide) (MTT) cell-based colorimetric assay was used in the cytotoxicity assessment. It detects the viable cells based on tetrazolium compound reduction after reacting with metabolized cells. If the cell metabolically actives, it has the ability to convert yellow MTT reagent into purple formazan by mitochondrial succinate dehydrogenase reaction. The intensity of purple formazan color solution was depending on the amount of viable cells that able to actively metabolize the tetrazolium compound in MTT reagent. Finally, high or low number of live cell was measured under spectrophotometer which gave the absorbance value of each well.

Mixture of methanol and water (hydromethanol) was used as solvent for extraction in this study. This means that polar solvent was used since methanol and water were classified as polar solvent. Hydromethanolic extract (mixture of methanol and water) has greater efficiency in pulling out (extract) phytochemical compound in plant compared to pure solvent (without mixture) [20,26,27]. Interestingly, in this study, it was found that both antibacterial and cytotoxic activities of this plant are considered weak. Even though $S$. polyanthum extracts do not demonstrate potent antibacterial and cytotoxic activities, it does not mean that the extract has poor therapeutic value. Perhaps, it is a possibility of phytochemical compound existing in the plants which are multicomponent mixture with different polarities. Selection of an appropriate solvent for extraction is crucially important since phytochemical compounds contribute to the therapeutic value of the plant. Therefore, further phytochemical analyses of this plant need to be conducted to determine phytochemical constituents and further isolation of the bioactive compound is strongly recommended.

\section{Conclusion}

Crude hydromethanolic extract of S. polyanthum exerts weak antibacterial activity. Overall, the extract can be considered weak cytotoxic to mammary carcinoma cells. However, it was more toxic to MCF-7 cells compared to 4T1. These results support the claims from traditional practitioner. However, further study is recommended, especially, this plant should be tested for in vivo. This is because many studies found that the effect would be different when tested between in vitro and in vivo, and perhaps, it would be more potent. This is because animals have an immune system and microenvironment such as hormone, and thus, the synergistic effect derived from extract might exist in vivo compared to in vitro.

\section{Authors' Contributions}

MLN involved in all aspects of the study including concept, design, data collection, interpretation of data, statistical analysis, and manuscript preparation. $\mathrm{AAO}$ and AAK involved in obtaining funding and assisting the experiment. RS, AYO, and MM contributed to the statistical analysis and evaluated the manuscript. All authors have read and approved the final manuscript.

\section{Acknowledgments}

The authors would like to thank the Faculty of Veterinary Medicine, UPM and Universiti Malaysia Kelantan, for providing the facilities and support for the completion of this study. The authors also are grateful to all the faculty staff who were involved indirectly in the study. This study was funded by Research University Grant Scheme (RUGS), Universiti Putra Malaysia (UPM), Malaysia (01-02-12-1670RU).

\section{Availability of Data and Materials}

The datasets generated and/or analyzed during the current study are not publicly available due to its part of a big study (data) but are available from the corresponding author on reasonable request.

\section{Competing Interests}

The authors declared that they have no competing interests.

\section{Publisher's Note}

Veterinary World remains neutral with regard to jurisdictional claims in published institutional affiliation.

\section{References}

1. Radostits, O.M. and Arundel, J.H. (2000) Veterinary Medicine: A Textbook of the Diseases of Cattle, Sheep, Pigs, Goats and Horses. $9^{\text {th }}$ ed. Saunders Press, London.

2. Zahreddine, H. and Borden, K.L. (2013) Mechanisms and insights into drug resistance in cancer. Front Pharm., 4(28): 3389 .

3. Townsend, D.M. and Tew, K.D. (2003) The role of glutathione-S-transferase in anticancer drug resistance. Oncogene, 22(47): 7369-7375.

4. Fathi, B., Jamshidi, A., Zolfagharian, H. and Zare Mirakabbadi, A. (2011) Investigation of the antibacterial effect of venom of the Iranian snake Echis carinatus. Iran. J. Vet. Sci. Technol., 2(1): 93-99.

5. Ang, J.Y., Ezike, E. and Asmar, B.I. (2004) Antibacterial resistance symposium series society for applied microbiology. Ser. Soc. Appl. Microbiol., 2004(3): 229-239.

6. Balunas, M.J. and Kinghorn, A.D. (2005) Drug discovery 
from medicinal plants. Life Sci., 78(5): 431-441.

7. Jain, R. and Jain, S.K. (2010) Traditional medicinal plants as anticancer agents from Chhattisgarh, India: An overview. Int. J. Phytomed., 2(3): 186-196.

8. Harvey, A.L. (2008) Natural products in drug discovery. Drug Discov. Today, 13(19): 894-901.

9. Park, M.H., Choi, M.S., Kwak, D.H., Oh, K.W., Yoon, D.Y., Han, S.B., Song, H.S., Song, M.J. and Hong, J.T. (2011) Anti-cancer effect of bee venom in prostate cancer cells through activation of caspase pathway via inactivation of NF-кB. Prostate, 71(8): 801-812.

10. Ahmed, U., Malik Mujaddad-ur-Rehman, N.K., Fawad, S.A. and Fatima, A. (2012) Antibacterial activity of the venom of Heterometrus xanthopus. Indian J. Pharm., 44(4): 509.

11. Noorma, W.H. (1995) Synzgium gaertner; plant resource of South East Asia No 5(2). In: Lemmens, R.H., Soerianegara, M.J. and Wong, W.C.I., editors. Timber Trees: Minor Commercial Timbers. Prosea Foundation, Bogor, Indonesia. p441-474.

12. Ismail, M. (2007) Ensiklopedia Herba: Kegunaan Dan Khasiat Perubatan Tradisi. Anzagain Sdn Bhd.

13. Dalimartha, S. (2007) Atlas of Indonesian Medicinal Plants. Vol. 2. Pustaka Penerbitan, Niaga Swadaya. p162-165.

14. Haque, M.M. (2004) Inventory and documentation of medicinal plants in Bangladesh. In: Medicinal Plants Research in Asia. Vol. 1. Bangladesh: The Framework and Project Workplans. p45.

15. Ismail, A., Mohamed, M., Sulaiman, S.A. and Wan Ahmad, W.A N. (2013) Autonomic nervous system mediates the hypotensive effects of aqueous and residual methanolic extracts of Syzygium polyanthum (Wight) Walp. var. Polyanthum leaves in anesthetized rats. Evid. Based Complement. Altern. Med., 2013: 1-16. Article ID 716532.

16. Widyawati, T., Yusoff, N.A., Asmawi, M.Z. and Ahmad, M. (2015) Antihyperglycemic effect of methanol extract of Syzygium polyanthum (Wight.) leaf in streptozotocin-induced diabetic rats. Nutrients, 7(9): 7764-7780.

17. Bauer, A.W., Kirby, W.M.M., Sherris, J.C. and Turck, M. (1966) Antibiotic susceptibility testing by a standardized single disk method. Am. J. Clin. Pathol., 45(4), 493-496.

18. Jorgensen, J.H. and Turnidge, J.D. (2007) Antibacterial susceptibility tests: Dilution and disk diffusion methods. In: Murray, P.R., Baron, E.J., Jorgensen, J.H., Landry, M.L. and
Pfaller, M.A., editors. Manual of Clinical Microbiology. $9^{\text {th }}$ ed. American Society for Microbiology, Washington, DC. p1152-1172.

19. Baharum, Z., Akim, A.M., Taufiq-Yap, Y.H., Hamid, R.A. and Kasran, R. (2014) In vitro antioxidant and antiproliferative activities of methanolic plant part extracts of Theobroma cacao. Molecules, 19(11): 18317-18331.

20. Nordin, M.L., Kadir, A.A., Zakaria, Z.A., Abdullah, R. and Abdullah, M.N.H. (2018) In vitro investigation of cytotoxic and antioxidative activities of Ardisia crispa against breast cancer cell lines, MCF-7 and MDA-MB-231. BMC Complement. Altern. Med., 18(1): 87.

21. Ayob, Z., Mohd Bohari, S.P., Abd Samad, A. and Jamil, S. (2014) Cytotoxic activities against breast cancer cells of local Justicia gendarussa crude extracts. Evid. Based Complement. Altern. Med., 2014: 1-12. Article ID 732980.

22. Mehta, N.R., Patel, E.P., Patani, P.V. and Shah, B. (2013) Nelumbo nucifera (Lotus): A review on ethnobotany, phytochemistry and pharmacology. Indian J. Pharm. Biol. Res., 1(4): 152-167.

23. Vashist, H. and Jindal, A. (2012) Antimicrobial activities of medicinal plants - Review. Int. J. Res. Pharm. Biomed. Sci., 3(1): 222-230

24. Ramli, S., Radu, S., Shaari, K. and Rukayadi, Y. (2017) Antibacterial activity of ethanolic extract of Syzygium polyanthum L. (Salam) leaves against foodborne pathogens and application as food sanitizer. Bio. Med. Res. Int., 2017: 1-13, Article ID 9024246.

25. Atjanasuppat, K., Wongkham, W., Meepowpan, P., Kittakoop,P., Sobhon,P., Bartlett,A. andWhitfield,P.J.(2009) In vitro screening for anthelmintic and antitumor activity of ethnomedicinal plants from Thailand. J. Ethnopharmacol., 123(3): 475-482.

26. Aktumsek, A., Zengin, G., Guler, G.O., Cakmak, Y.S. and Duran, A. (2013) Antioxidant potentials and anticholinesterase activities of methanolic and aqueous extracts of three endemic Centaurea L. species. Food Chem. Toxicol., 55(2013): 290-296.

27. Al-Barazanjy, R.K., Dizaye, K. and Al-Asadye, A. (2013) Cytotoxic and cytogenetic effects of Salvia officinalis on different tumor cell lines. Middle East J. Int. Med., 6(4): $15-25$. 